\title{
King's monuments: identifying 'formlings' in southern African San rock paintings
}

\author{
Siyakha Mguni*
}

The author demonstrates that the complex images of rock art known as formlings depict or evoke the equally complex architecture of ant-hills. Presented in cutaway and full of metaphorical references, they go beyond the image into the imagination.

Keywords: Africa, Zimbabwe, San, rock art, ant hills, formlings

\section{Introduction}

A formling is a particular category of San rock art image that occurs in Zimbabwe in its thousands (Garlake 1990: 17), although a few occur in northern South Africa (Mguni 2002) and some in western Namibia (Mason 1958) (Figures 1 and 2). Some of the finest examples occur in Matopo where there is a correlation between their complexity in terms of care and detail in their execution and central placement in large shelters with deep occupation deposits (Walker 1996: 32, 60, 73). Formlings also stand out in their contextual associations with a range of other paintings (Garlake 1987, 1995; Walker 1996). They seldom occur in isolation; their contexts include images of various large and small animal species and varied invertebrate taxa. Giraffes are most common, followed by kudu, although kudu dominate across all Zimbabwean rock art (Walker 1996: 73-4).

Perhaps the most prevalent and consistent formling association is with plants and trees (Mguni 2002). Plants are painted next to formlings, at times grow on their tops or from their edges. Formlings and plants are sometimes conflated in a complex manner. Anthropomorphic associations include people, ethereal human-like figures and therianthropes (part-animal/part-human figures). Many of these contexts and conflations have not hitherto been properly investigated, yet together they hold the key to our understanding of formling subject-matter and its significance. Emphases and the choice of subjects vary in different regions, but Zimbabwean paintings are not widely differentiated from the rest of southern African San imagery. Similar artistic conventions are applied and all suggest 'a product of the same society and same artistic tradition' (Garlake 1987: 83).

Defining and describing the morphology of the formlings is essential in any quest for their subject-matter, and this in turn is critical to interpreting their symbolism. From the

* Rock Art Research Institute, University of the Witwatersrand, South Africa and Bushmans Kloof Wilderness Reserve and Retreat, South Africa (Email: siyakha@bushmanskloof.co.za and siyakha@rockart.wits.ac.za) 


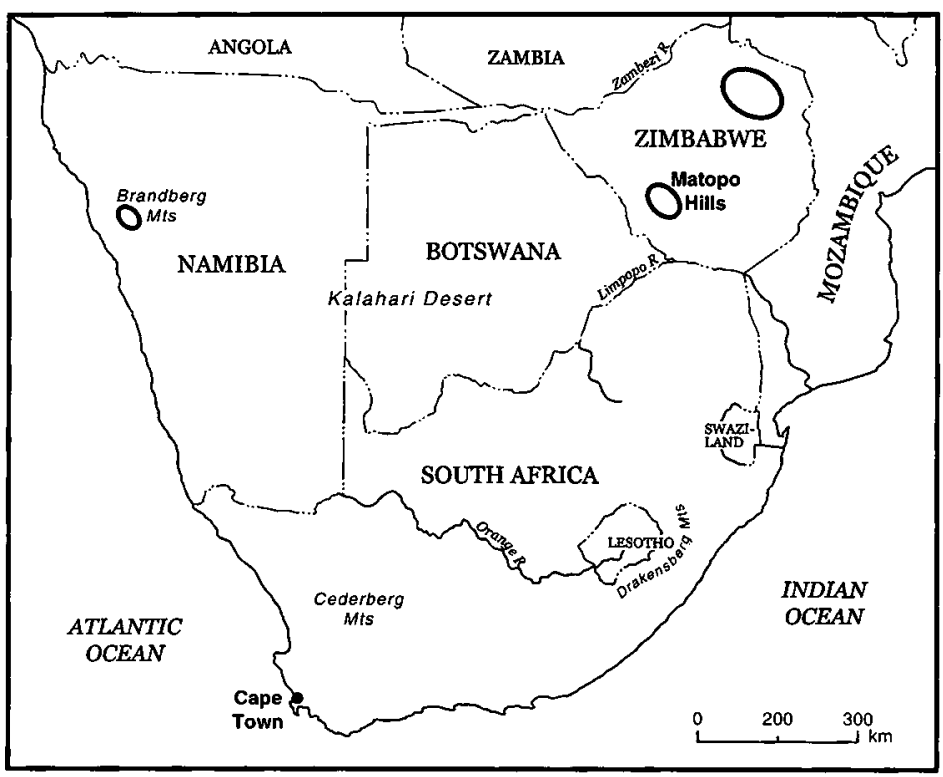

Figure 1. Map showing San rock art distributions in southern Africa. Circled areas show localities where formlings are found (Mguni 2002).

definition of formling morphology follows the applied concept of these paintings as 'cultured imagery', which particularises San artistic principles. It introduces an insider's perception and purpose for which rock art was produced (Mguni 2002, 2004). Imagery in a cultured system works by a set of principles; these express cultural judgements and priorities in what the imagery does and does not represent, and in how it chooses to embody various symbolic subjects. The principles of San rock art, like those of all other rock art traditions, are largely coherent with other traits in the larger San cultural world. Subjects were selectively treated graphically to emphasise or underplay aspects of symbolism, archaeologically evident to us in the material images we see, and of which the logic of formlings is part, and which will be consistent with the larger pattern of San society and the San worldly and non-worldly experiences.

This paper defines formlings, then charts their previous interpretations and finally, identifies their subject matter.

\section{Definition of formlings}

Recognising the pattern as a distinct category, Leo Frobenius $(1930,1931)$ coined the word 'formlinge,' to mean a form with a range of composite shapes (Goodall 1959: 62). They are peculiar because, to the uninitiated, they are unrecognisable. They may however be conveniently defined by distinctive features under the headings essential features (contour, outlines, cores, interstices) and additional features (orifices, crenellations, microdots, oval flecks, caps, cusps). I argue that ten features, isolated in bold below, delineate formlings as a unique category (Figure 2). 
Siyakha Mguni

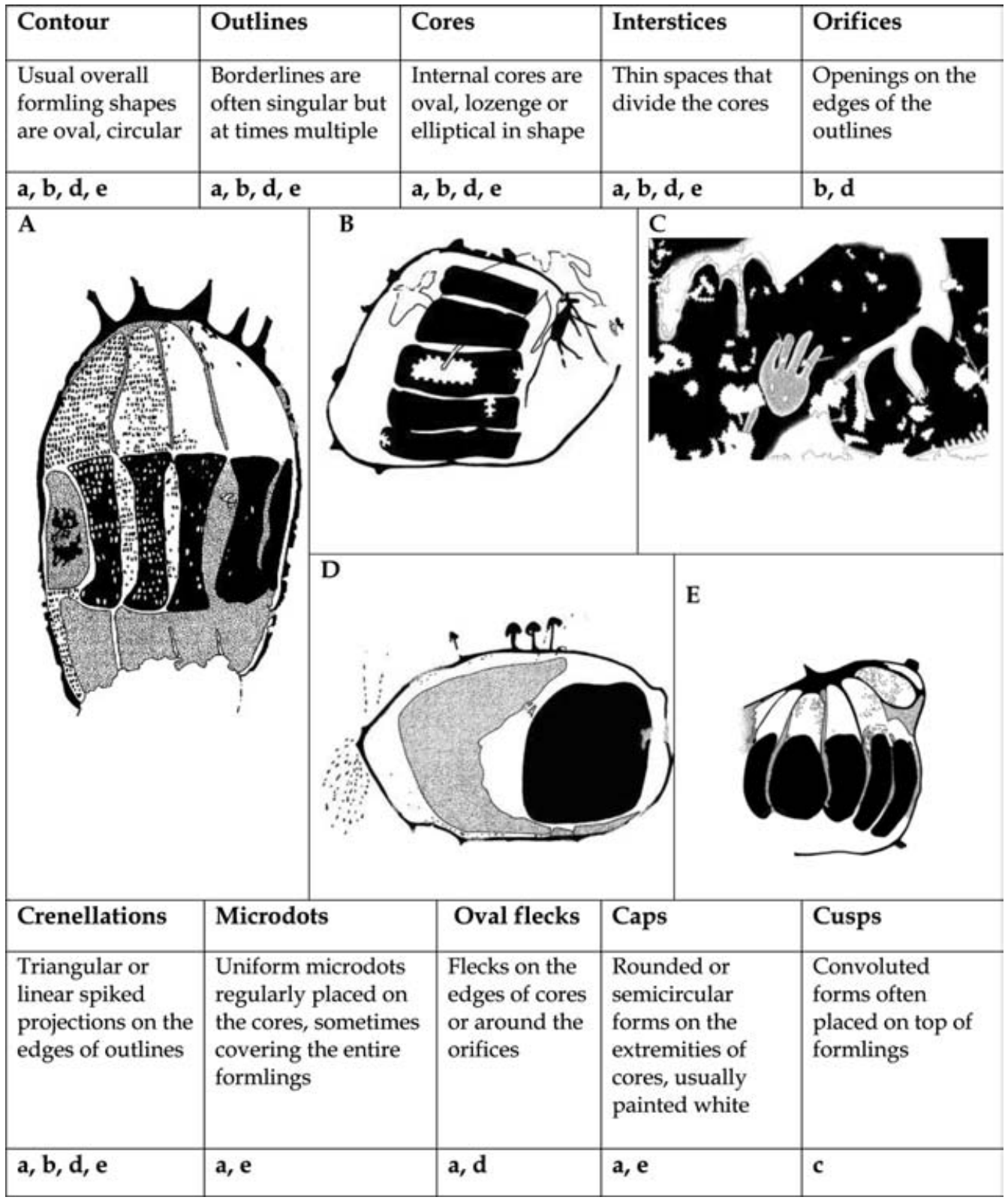

Figure 2. A composite diagram showing a selection of formlings with the typical features as defined in this study $(A, B, D, E$ redrawn after Garlake 1995; C, after Mguni 2002).

\section{Essential features}

The overall contours of formlings range from oval to circular forms. In examples lacking the lines that define their contours, this form is inferable from the arrangement of their other distinctive features. I call these defining lines (often single, at times multiple) outlines. Sometimes they are weathered, or they were never painted at all, but the main features 


\section{'Formlings' in San rock paintings}

remain positioned in a similar manner to those in formlings with outlines. Varying sizes of discrete formling cores are often oval- or oblong- or elliptical-shaped, with longitudinal sides nearly parallel. Their slightly concave midsections are usually red, with white extremities. Cores are rarely single, but occur in clusters of up to ten or more per formling. They appear as sets, placed in a line vertically, side-by-side, or stacked horizontally, one above the other. Formlings are thus a 'composite type of forms' (Goodall 1959: 62) comprising sets of cores. This is the sense in which 'formlinge' was originally intended. A single core cannot be called a formling. Almost invariably, cores are separated byinterstices, narrow spaces in-between. At times, cores are conjoined. This may be due to weathering that blurs their edges or pigments washing into each other, but some variants appear to have been intentionally conjoined.

\section{Additional features}

Supplementary formling features are recognisable. On the edges of outlines are single orifices, often associated with oval flecks. They occasionally protrude outwards in the manner of a teapot spout (Figure 6). Some formlings have triangular or linear spiked crenellations on their outlines, sometimes all around the outer edges of outlines, or at the top or the base of formlings. Frequently, cores are covered with grids or lines of regularly spaced and standardsized microdots (Walker 1996: 32). Usually white, these dots are sometimes red where the background is lighter.

Oval flecks cluster on parts of or around the outlines or inside the formling cores. They sometimes appear as trident or winged forms. Another fleck type, based on short strokes, is irregularly painted to cover wider areas beyond formlings. Because this fleck type occurs with other imagery and thus is not unique to formlings, I regard it as inconsequential to their definition, although some writers associate them with potency (Garlake 1995: 103). Although allied in formlings, oval flecks and microdots depict different subjects to which I later return. Semicircular white caps frequently form the rounded extremities on one or both ends of the cores. Cusps are a similar feature, but they appear as serial convolutions or nebulous forms on top of formlings. Their patterning tends to be irregular.

Formlings may not carry all these features in repeated combinations and they seldom all appear on a single image. A strong pattern emerges however once a typology of a range of formlings is assembled. Often, only a few features were selected and depicted in varying combinations. Some elements such as cores, interstices, microdots and flecks are almost invariably present. This consistency typifies formlings as a distinct and coherent category. Variability falls within a limited range of features, which remain consistent in all areas (Garlake 1995: 92). Variation is a hallmark of San rock art; regional variations of subjects are common, but their distinctive features remain constant. With this definition, I now turn to previous identifications, which were highly selective of these features.

\section{Previous identifications}

One formling was identified as the Victoria Falls (Hall 1912: 595). Subsequently, Frobenius (1929: 333) suggested granite boulders and hilltops. This view later became generally accepted (Breuil 1944: 4; Goodall 1959: 60-6; Cooke 1959: 42; Lee \& Woodhouse 1970: 140-2). Formlings were also identified as cultural and natural phenomena: skin cloaks called 


\section{Siyakha Mguni}

'karosses' (Goodwin 1946: 17), a stockaded village and mud huts (Rudner \& Rudner 1970: 86-7), beehive (Cooke 1959: 146), cornfields, quivers, mats, xylophones (Cooke 1969: 42), grain bins (Holm 1957: 9), strato-cumulus thunderclouds (Rudner \& Rudner 1970: 87), and pools of rainwater (Breuil 1966: 115-6).

These identifications derived from weak resemblances between formlings and their supposed subject-matter. They were nonetheless consistent with understanding San images in terms of the physical world the San inhabited. Because formlings did not seem closely to resemble any of these subjects, some writers suggested them to be background décor in shelters (Mason 1958: 363). Others admitted to being completely mystified that they became contented with 'whatever conclusion the imagination leads the observer' (Cooke 1969: 42). Not all writers were resigned to this relativistic agnosticism. Frobenius (1930), for instance, argued that formlings symbolised the 'king's monuments', noting that they decorated royal tombs. Guided by a mistaken association of the paintings with recent Iron Age and historical burials in these shelters, he applied inappropriate ethnography. In eastern Zimbabwe Shona chiefly lineages are still buried in shelters (Tore Saetersdal pers. comm.). The bulk of San paintings predate these recent occupation phases.

Still, formlings were regarded as unidentifiable abstractions. Mason (1958: 362-3), for example, suggested they were 'decorative abstract motifs... not based on nature'. But this view is inconsistent with our present knowledge of San imagery, its operational principles and specifically the range of formling contexts. Without the benefit of direct informed knowledge from the artists (Parkington 1989), I advocate a composite analysis that relies on the morphological elements, San ethnography and the expressive principles inherent in the images themselves (Chippindale \& Taçon 1998: 7-8).

\section{Previous interpretations}

In the 1970s San rock art became routinely studied against relevant parallels established from San ethnography (Vinnicombe 1976; Lewis-Williams 1981). This paradigm guided us to learn from the San artists' life, belief and cosmology, and taught us to expect meanings that transcend the physical subjects. Current formling interpretations therefore draw specifically on notions of supernatural potency (Garlake 1990, 1995; Walker 1996).

\section{Potency of bees and honey}

One formling has been interpreted as a beehive (Cooke 1959: 146), a view that was later elaborated to include honeycombs, bees and honey-gatherers (Pager 1971: 347-52, 1973: 61) or prehistoric apiculture (Guy 1972; Crane 1982; Woodhouse 1990). The bulk of these images comprise nested ' $U$ ' shapes, multiple curved lines and ovals, often aligned in rows, forming horizontal segments. Harald Pager (1976: 2) argued that this was a 'worm's eye view' of parallel sets of honeycombs seen from beneath. Subsequently, formlings were linked with San beliefs about the potency of bees and honey (Huffman 1983: 50-1). Indeed, this is plausible in the Drakensberg (and some sites in Zimbabwe) where the images explained in these formal terms correspond with beehives and honeycombs (Figure 3). However, these images are distinct and bear limited resemblance to formlings. Hence new views have been proposed for the broader, unidentified, category. 


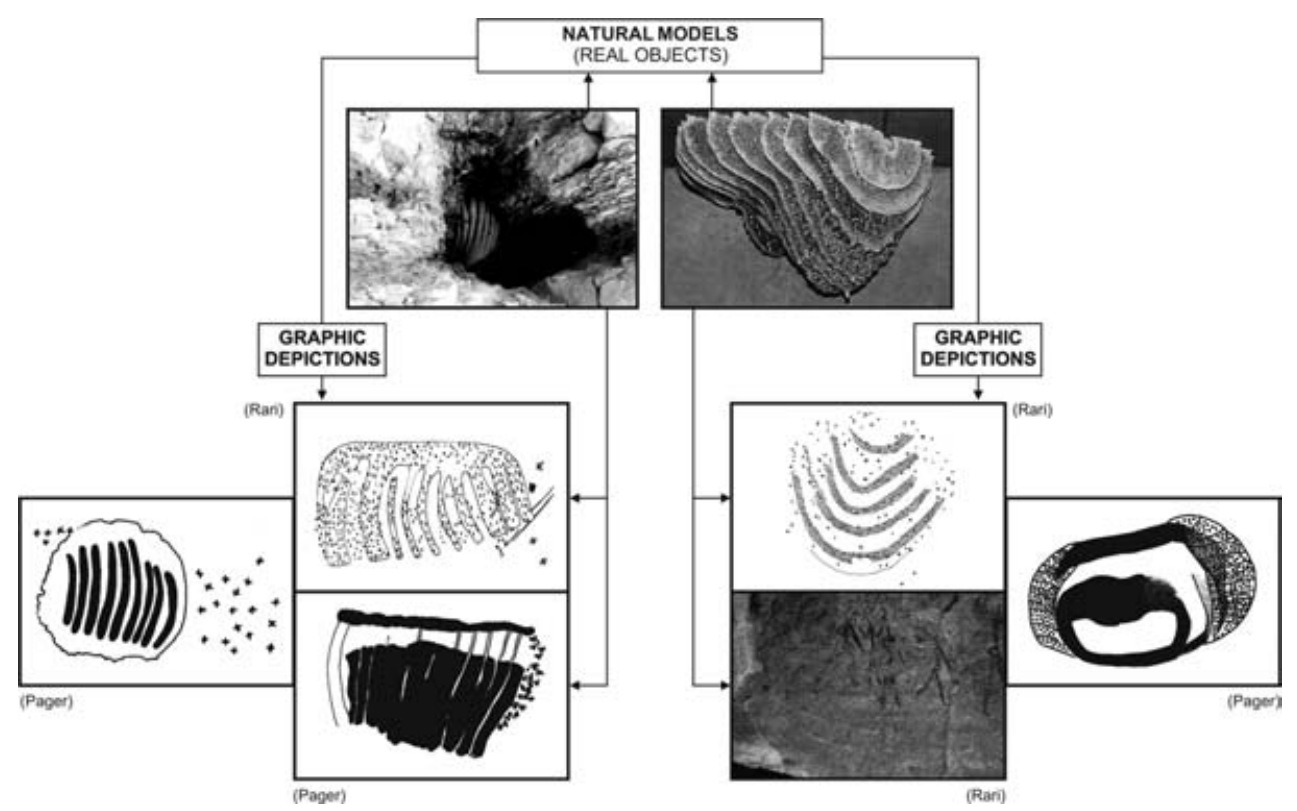

Figure 3. An illustration showing the manner in which honeycombs and beehives are depicted in the south-eastern mountains of South Africa and Lesotho (after Mguni 2002).

\section{Metaphorical maps}

Another cluster was interpreted as showing metaphorical 'maps' (Smith 1994) of San outof-body journeys. Although carefully constructed, the relevance of the Ju/'hoansi concept of $n$ !oresi, on which the argument is based, is doubtful in formling contexts. For instance, the San exploitation ranges are weakly defined and fluid, though specific points such as waterholes and beehives were owned and, at times, marked. Cartographic concepts of mapping space as solid areas may be alien to the San who often think of these territories as points, sometimes with radiating lines as paths that people travel to hunt or gather (Marshall \& Ritchie 1984: 83). Further, no ethnographic testimonies suggest that the spirit world is subject to earthly principles of territoriality and resource ownership.

\section{Gebesi and potency}

A remarkable panel of an oval core associated with a human abdomen was argued to represent the gebesi-abdomen-specifically the liver and spleen (Garlake 1995: 96, 154). Another nearby human figure has similar, but elongated, cores along its body. In this view, formlings are potency symbols (Garlake 1990: 19). Whereas these two examples support this analysis, some images similarly conflate cores with plants and animals, such as a crocodile's belly (Garlake 1995: 119). This association is therefore not unique to human abdomens (Walker 1996: 75). Nevertheless, this idiosyncrasy is a feature of San religious revelations and rock art (Dowson 1988: 117).

These studies have correctly placed formlings within the realms of San life, belief and ritual. But several areas remain unexplained. Whereas formlings are diverse, the regularity 


\section{Siyakha Mguni}

and coherence of their features is also remarkable. This consistency indicates that formlings originate from a particular physical reality, which must be probed through their contexts and shape features.

\section{Formling painted contexts}

My journey of understanding formlings began in 1993 after reading Pager's book Ndedema (1971). In the summer of 1997, four years later, I hiked the Ndedema Gorge, Drakensberg, visiting 17 sites where Pager had spent three years copying images in the 1960s. Today, his extraordinary reproductions, amounting to over 4000 images, offer an unparalleled treasury of South African rock art. I was enthralled by the prevalence of nested ' $U$ ' shapes and multiple curved lines attended by winged forms. These are now accepted as bees, beehives and honeycombs. Formlings were, as we have seen, mistakenly subsumed under this explanation: one Matopo painting (Figure 4), at Toghwana, was argued to depict

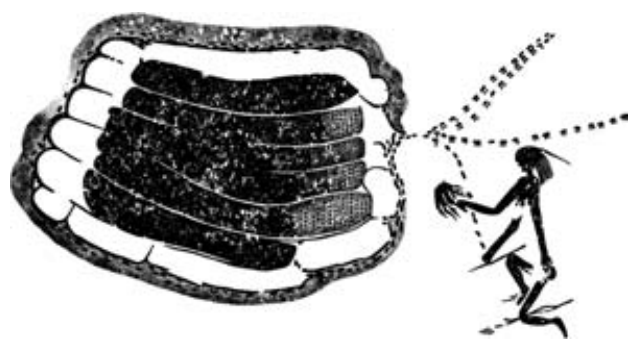

Figure 4. A formling associated with oval flecks, winged insect forms and human figure holding an object next to the orifice (Redrawn after Pager copy in RARI archive).

a honey gatherer smoking out honeybees from their nest (Pager 1973: 6-7, 1976: 1). I was initially convinced by this interpretation, but disparities between these images and formlings in Matopo required that formlings be re-examined critically.

In 1999 I reassessed the formling in Figure 4. Examining Pager's original copy on site, I was able to confirm its accuracy: first, indeed the images have wing-like appendages, and, secondly, some are inverted. Naturally, I questioned this detail: if these appendages were wings, why would they face downwards on some insects? Did some of these 'bees', as Pager argued them to be, have legs only while some had wings only? In the Drakensberg 'bees' appear with upright wings only, never with legs. These are minutely painted with red bodies and white pairs of wings. Some sites in Zimbabwe, too, follow this pattern (see Patie 1974), suggesting similarities of conventions for depicting these insects. Figure 4 appears to fall outside the usual convention used for bees, and therefore might depict something other than bees.

Further investigation of these images began with a re-evaluation of Pager's (1976: 6) suggestion that formlings might be the nests of stingless bees (Trigona spp.). Later some, in fact, had even conjectured other invertebrate forms, such as paper wasp nests or insect cocoons (Walker 1996: 73). Can the Toghwana images, and formlings in general, depict these insects and nests? Some complex details of formling features that I specified are inconsistent with the basic nest forms of these insects. Or, could these insects be locusts (or grasshoppers)? There is a rock art precedent in northern South Africa where locusts appear with pronounced back legs and large heads (Edward Eastwood pers. comm.). But, locusts and nesting holes too are outside the realm of formling features.

If the inverted appendages on some Toghwana images are legs, there is a possible candidate for this form: termites. Unequivocal flying termites were actually depicted in Matopo (Walker 1996: 73-4). At Silozwane a termite is clearly defined with head, abdomen complete with 


\section{'Formlings' in San rock paintings}

veined wings and spines while similarly winged termites swarm next to a formling at Nanke. Another cluster of termites in Matopo shows their elongate wings, clearly split and curving upwards as they do naturally during flight (Parry 2000). Comparatively, a site in Maclear (southern Drakensberg) shows similar images of termites (Dawn Green, pers. comm.) associated with a human figure and an eland bull, again suggesting similar artistic conventions in these regions. Are the Toghwana images therefore depictions of flying termites? Termites do in fact shed wings after nuptial flights to move on their legs searching for a nesting place, which probably explains the intriguing inverted images at Toghwana. Now, if we accept cautiously these to be termites, it is worth investigating their association with formlings.

\section{Association of formlings with termites}

To investigate this association I examined the formling morphology against the architecture of termite's nests. The artists' purpose to communicate symbolism influenced the choice of the viewing angles and details of significant subject features. The prediction is that formlings depict their subject in side-view (a dominant principle of prehistoric rock art, Deregowski 1995), as does the bulk of San imagery. While this does not solve the difficulty of recognising them, it provides a starting point in perceiving their 'correct' orientation. Associated insect forms, which I suggest to be termites, also indicate fortuitously another clue to evaluate our perceptions.

Of the 281 genera of termites (Isoptera) known worldwide, 54 occur in southern Africa (Uys 2002: 4). Most species build 'separate nests', both subterranean and epigeal types, which are a typical landscape feature of the savannahs. They also nest in rock shelters. While there is wide variability in nest forms, those of fungus-growers (Macrotermitinae subfamily) possess remarkable architectural complexities. With the actual nests usually centrally housed below ground level, their superstructures take the form of mounds and chimneys. However, some species of Apicotermes, another widespread genus in Africa (Howse 1970: 97, 113), are of interest because of their architecturally refined and delicate nests. Their nests are often ovoid, with well-defined internal galleries, which are sometimes structurally regular and symmetrical. Other species in the Hodotermes genera (harvester termites) and Amitermes construct compact and invariably spherical subterranean nests. These nests divide into numerous chambers by horizontal and vertical partitions (Howse 1970: 83, 98). Nests however vary considerably even within same species (Noirot 1970: 110; Howse 1970: 82), but their basic elements remain constant. While no nest is a replica of another, their distinctive features include the habitacle, idiotheque, chambers/cells, walls separating cells, exit ramps for nuptial flying (though not in all species), chimneys, pores/slits on habitacle exteriors, fungus combs and gardens among fungus-growers, moundlets or 'surface boils' on some nests and the insects themselves in various developmental phases. I now dissect these nests, feature-by-feature, to verify any correspondence their distinctive characteristics might have with the formling morphology (Figure 5). These are:

\section{Formling contour $=$ Habitacle shape}

Most underground nests are built in a sub-spherical volume (cavity) called the copularium. These cavities have protective empty spaces surrounding the habitacle, which is the actual 


\section{Siyakha Mguni}

nest containing the termite colony. These habitacles in most species are typically spherical or ovoid in form. In Macrotermes these can be the size of a football (Noirot \& Darlington 2000: 123). Viewed in cross-section, the contour of the outer wall is replicated in the circular or oval contour of formlings. There seems to be an equivalence between the contour of formlings and most nest forms.

\section{Outlines $=$ Idiotheque}

Clayey shells (idiotheque) encase the habitacles. These sub-spherical luminar walls often consist of several layers in some Macrotermes species (Noirot \& Darlington 2000: 123). They also vary in thickness according to species. Bellicositermes natalensis, for example, build thick and massive walls, whereas species in the genus Amitermes construct very thin walls. This wall feature recalls the outlines (single, multiple) of formlings.

\section{Cores $=$ Cells $/$ chambers}

The habitacle interiors are revealing. The Macrotermes and Odontotermes genera construct nests in large centralised, subterranean cavities that consist of various chambers, often compartmentalised like shelves. These contain fungus gardens and, near the centre, the royal cell with the physogastric queen (Uys 2002: 49-52). Some nest interiors of Apicotermes species, such as $A$. arquieri are always developed by divisions into floors, regularly superposed by concave partitions in a generally horizontal aspect. These partitions are joined towards the axial part by a complex system of ramps that also serve as communication in a vertical direction (Noirot 1970: 114). In A. lamani, simple pillars with short ramps unite these concave partitions to form distinctive chambers or cells (Howse 1970: 114). These chambers or cellular structures (variously extending vertically and horizontally) are formally similar to internal oval- or elliptical-shaped formling cores.

\section{Interstices $=$ Cell walls}

Distinct walls, often thin, separating chambers/cells inside habitacles define and give form to this internal partitioning. These walls are generally horizontally aligned, but sometimes they have short vertical orientations as dictated by the general structure and alignment of the chambers. Such walls dividing inner partitions of chambers in termites' nests are replicated by the interstices between formling cores.

\section{Orifices $=$ Launch pads}

Nests often have complex gallery systems, usually comprising of almost vertical or upwardly projecting channels at the top of the nest, but also connecting the cellars near the base (Noirot 1970: 97). In Odontotermes transvalensis, these features project above ground to heights of $1.3 \mathrm{~m}$ or more (Coaton 1947). In Macrotermes bellicosus, chimneys in well-vegetated areas may be narrow to resemble cathedral spires (Howse 1970: 96). These regulate climatic control or gaseous exchange inside the nests (Howse 1970: 107; Turner 2000: 143; Uys 2002: 50), but in some species they occasionally also serve as exit ramps of termites or 


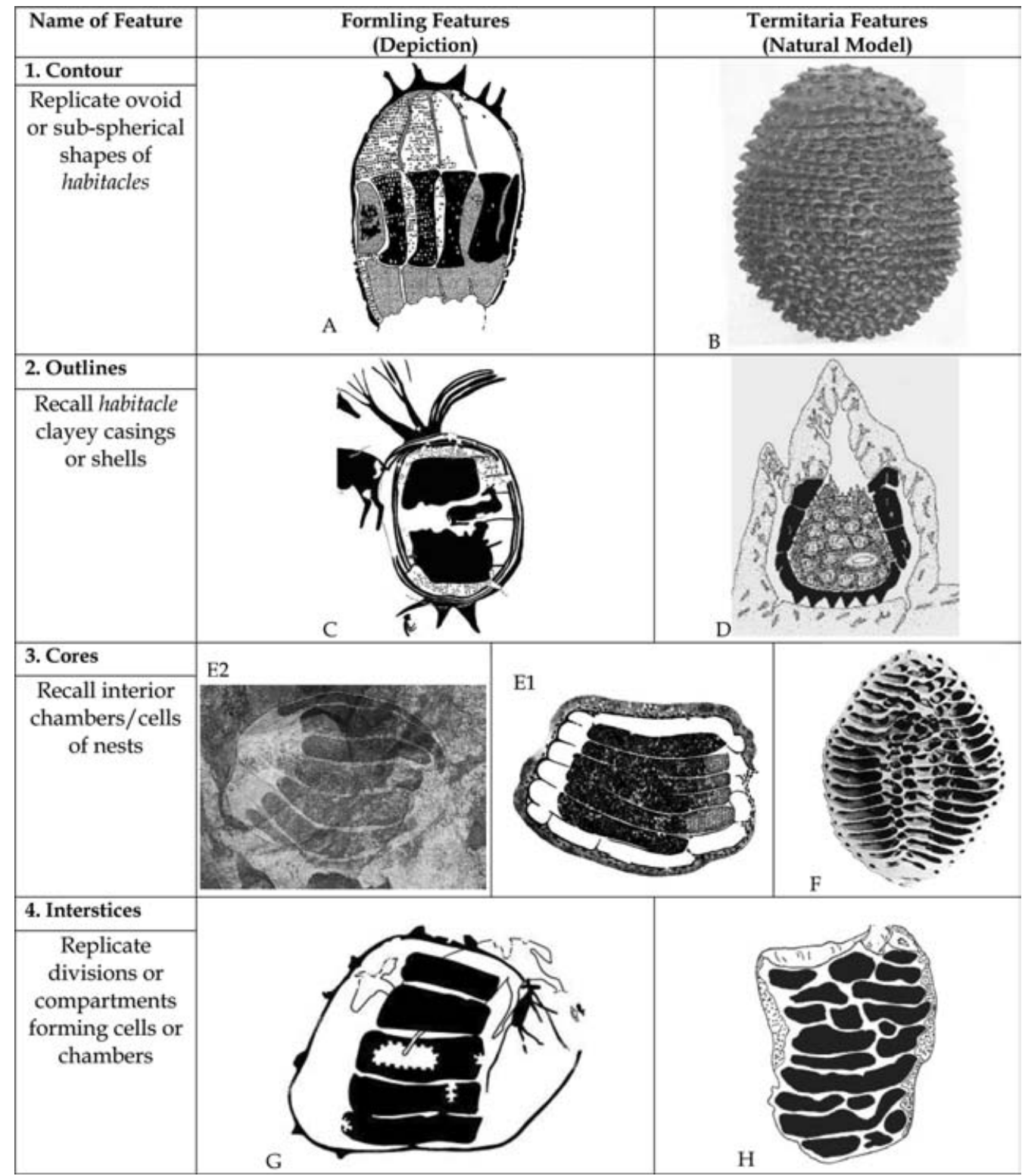

Figure 5. Correspondence between graphic features of formlings and architectural details of termite nests: formlings and the interiors of termitaria are projected in a sectional view, $(A, G, I, K, O, S, T$, after Garlake 1995; D, F, M, after Krishna \& Weesner 1970; J, T, U, W, after Uys 2002; B, H, after Howse 1970; E, N, R, after Pager Copy RARI archive; C, L, Q, after Mguni 2002).

as emergence towers for flying termites (alates) in their nuptial flights (Howse 1970: 92). Some species however construct temporary launching pads before swarming (Uys 2002: 44, 46), which look like miniature openings that the San call !honno (Bleek 1956: 398). Before swarming P. spiniger build similar, but domed structures as launching pads (Howse 
Siyakha Mguni

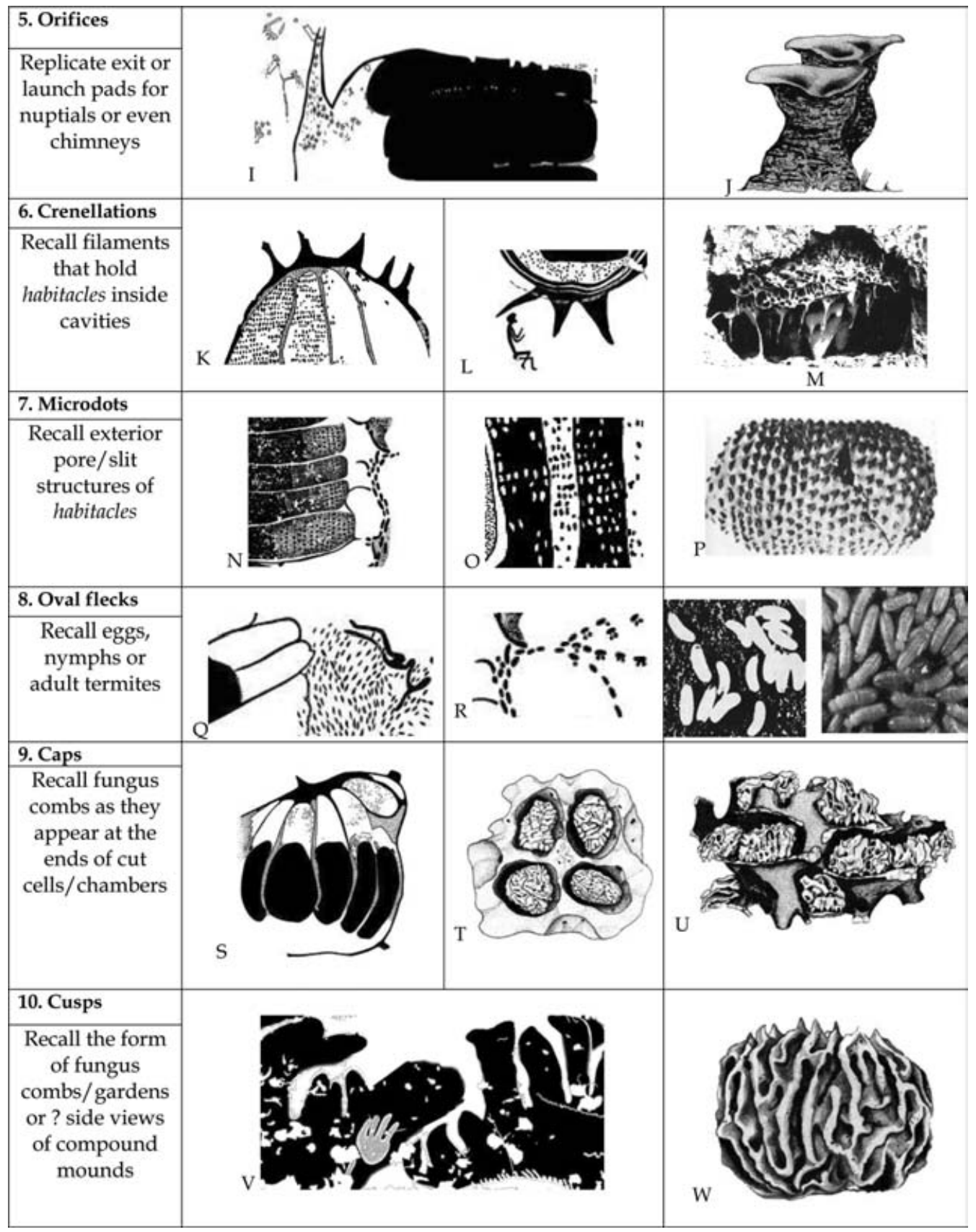

1970: 92). Formling orifices, sometimes protuberant and elaborate, allude to these features of nests (Figure 6). Chimneys or launching pads are associated with mounds and therefore San artists may not have differentiated them in the paintings. 


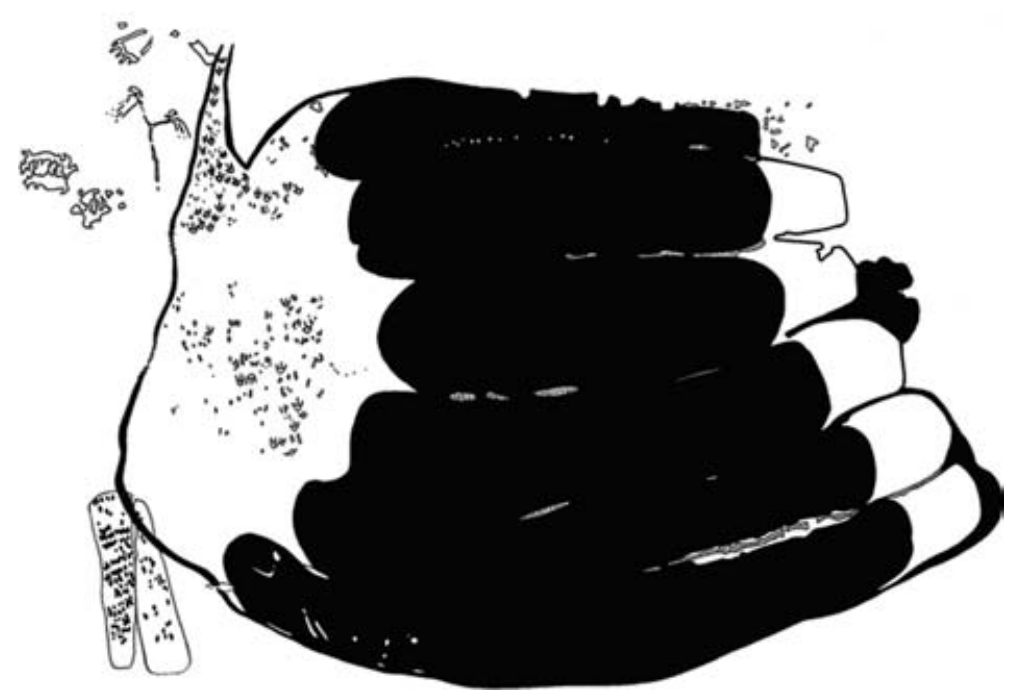

Figure 6. Formling depicting termites inside the interiors of their nests and other associated features in an ecosystem (redrawn from Garlake 1995).

\section{Crenellations $=$ Support pillars or Pinnacles}

The exterior of the nest walls has complex features that differ in details of form in various species. Nests are usually supported at the base (also on the sides and at the top) inside the underground cavities on conical pillars. These are often regular with points directed away from the habitacle. These features can 'extend into the cave by very thin and fragile filaments' (Noirot 1970: 101) to appear as a spiky exterior morphology of the habitacle. In aged nests of $B$. natalensis, the central pillars can be hypertrophied to lengths of about $50 \mathrm{~cm}$ or more while the shorter peripheral ones remain suspended from the bottom. Another notable feature, particularly with Macrotermes natalensis, is the heavy fluting on outer walls of habitacles to form prominently projecting 'ribs' or pinnacles (Noirot 1970: 108). These features on the exterior wall of nests are replicated on formling outlines as triangular or linear spiked crenellations on their fringes.

\section{Microdots $=$ Pores $/$ slits}

The greatest complexity of nests occurs in the structure of their exterior walls. These idiotheque have a system of regularly arranged rows of either pores or slits indirectly opening into the nest chambers (Howse 1970: 98) to facilitate ventilation and communication with the exterior. Macrotermes natalensis construct special galleries between the ducts on the interior and exterior of nests, which appear as horizontally aligned openings on the outside of walls that are sometimes slit-like (Howse 1970: 50, 99). Regularly patterned grids of microdots on formlings replicate this feature of nests.

\section{Oval flecks $=$ Eggs, nymphs, apterous termites}

Oval flecks are sometimes directly mixed with unequivocal flying termites, or winged and legged forms. This indicates relationship with these invertebrates. They can therefore be 


\section{Siyakha Mguni}

recognised as wingless termites (workers/soldiers), or nymphs, with barely visible wing-pads or even eggs. Their clustering on the edges of formling cores, sometimes inside, is suggestive of termite aggregation behaviour, generally associated with nymphs to establish cohesiveness and functionality of termite colonies (Nalepa \& Bandi 2000, 61).

\section{Caps $=$ Fungus combs/agarics}

Inside the nests of fungus-growers a much lighter clayish structure comprises the royal cell and chambers with fungus gardens. These are whitish fungus combs, a distinctive element of these cells. A symbiotic genus of fungi, termitomyces (Howse 1970: 19, also known as 'beefsteak mushrooms' (Levin et al. 1985: 16), grows from these combs and, occasionally during the wet season, develops into agarics (Uys 2002: 56-7). This phenomenon appears to be depicted as white semi-circular caps on one or both ends of formling cores. These caps often assume hemispherical to convex shapes similar to the caps of the fruit bodies of termitomyces (van der Westhuizen \& Eicker 1994: 9). The white pigment used is probably not accidental. But this feature is depicted in more stylised and conventionalised manner than naturalistically. Whereas Figure 2D could be a depiction of agarics above an underground nest, those forms could also be plants, as mounds are frequently associated with trees or other vegetation (Turner 2000: 151), an association strongly suggested in Figure 6.

\section{Cusps $=$ Moundlets/fungus gardens}

Above-ground nests of some species have 'surface boils' (Turner 2000: 158-9) forming clusters of domes. Macrotermes natalensis mounds are especially striking, often clustered with numerous moundlets (Turner 2000: 164). Older nests have gigantic mounds. Domes cluster around these parent nests, as in Macrotermes bellicosus, with the development of accessory nests (Noirot 1970: 91). Cusps may therefore be a cross-sectional rendition of moundlets as seen from a 'shadowed' lateral viewpoint. At Nanke this viewpoint is depicted as two merged domes surrounded by flying termites. Cusps on the upper fringes on some formlings retain a 'jumbled' appearance, which, like the caps, may allude to fungus gardens and clusters of agarics. But cusps also take another form that can be explained in terms beyond nests. At times this feature comprises convolutions that are delicately outlined in white on their edges. In others, only repetitive semicircular outlines are depicted. This image is explored in a forthcoming study.

A final notable feature of formling contexts is that of consistently depicted curious objects held by associated human figures. In one painting (Figure 4), this was argued to be a torch used by a honey gatherer to smoke bees out of a nest. Considering its tufted form, it might be the grass bundles which some San use as plugs to block flying termites from escaping nests, a harvesting strategy that ensures collecting large quantities of the insects in one haul (Nonaka 1997: 30-1). This places formlings within a specific aspect of San hunter-gatherer economic way of life, termite exploitation.

The pertinence of the Macrotermes and Odontotermes genera among the fungus-growing termitids and Apicotermes genera is now clear. Their preferred ecosystems and biogeography (see distribution maps: Uys 2002: figs 95, 118, 140) seem to avoid high altitude, wet and 


\section{'Formlings' in San rock paintings}

relatively colder climate (Bignell \& Eggleton 2000) such as found in the Drakensberg and Maloti Ranges (Figure 1). This distribution correlates neatly with that of formlings. This observation should, nonetheless, not be seen as the only reason why the Southern San in the Drakensberg seldom painted formlings. Neither does this observation make termites and nests any less significant in their life and belief. Certainly, a converse regional feature is the over-representation and emphasis of the eland in relation to other animals as a key in South African rock art. While eland are rare north of the Limpopo, their significance in San belief is acknowledged across southern Africa (Lewis-Williams 1981).

\section{Formlings find their natural model}

To have correspondence only in one or two features between formlings and termite nests might be coincidental. But for all the ten formling features to be recognisable as a single natural subject identifies them most plausibly as nests. The features of the nest do not necessarily have to appear in their entirety on any one formling. This is not to be expected, as San images do not usually carry all the features of their subjects, such as some depictions of hornless eland. In addition, although the artists focused on the nests of fungus-growers they seem often to have conflated their features with those of nests of other species.

The relatively homogenous conventions of San rock art in the choice of subject associations of plants, animals and with termites identify formlings as nests. In this imagery significant subject features were carefully chosen for depiction with essential features highlighted. In formlings the artists chose an aspect of nests which is not usually visible in ordinary circumstances, the interior view. They emphasised the interior structure of nests, showing it in cross-section. Yet this subject focus does not signal itself immediately to uninformed viewers. And some features were omitted while some were painted and highlighted. San images were conditioned less by the desire to produce facsimile copies of subjects than by the wish to capture those often hidden, but significant, subject elements. This is an art of metaphors, themselves presented minimally and powerfully. Now there is congruence of iconographic variation in formling morphology, which allows the use of relevant ethnography to explain the significance of termites and their nests in San thought and belief. In turn, this revelation unlocks the symbolic meaning of formlings, previously problematic. The nests, while being potent supernatural mediators of the San cosmos, were also symbolic avatars of a spirit world entity that has unparalleled transformative and generative powers.

\section{Acknowledgements}

I thank Swan Fund for fieldwork funding and the Rock Art Research Institute support, David Lewis-Williams, Benjamin Smith and my colleagues. Christopher Chippindale, Janette Deacon, Peter Garlake, Edward Eastwood, Sven Ouzman, Meg Cumming and Methew Mitchell are all thanked for their useful comments at various stages of the project. I also thank Carolyn Crump, Marcus Byrne and Anthony Cunningham from the Botanical and Zoological Sciences for their support of my initial identifications. Vivienne Uys (termitologist) and Rob Toms (entomologist) are especially thanked for their specialist input. I thank Wendy Phillips for some image bromides. Finally I thank the anonymous reviewers and the editor for their useful comments. The contents of this paper are my responsibility. 


\section{Siyakha Mguni}

\section{References}

Bignell, D.E. \& P. Eggleton. 2000. Termites in ecosystems, in T. Abe, D.E. Bignell \& M. Higashi (ed.) Termites: evolution, sociality, symbioses, ecology: 121-39. Dordrecht: Kluwer Academic.

BleEK, D.F. 1956. A Bushman dictionary. New Haven: American Oriental Society.

BreuIL, H. 1944. South African rock-paintings: landscapes of the soul, trans. M.E. Boyle. (Prologue for Walter Battis Exhibition).

-1966. Southern Rhodesia: the district of Fort Victoria and other sites. Paris: Singer-Polignac Foundation/Trianon Press.

Chippindale, C. \& P.S.C. Taçon (ed.). 1998. The archaeology of rock-art. Cambridge: Cambridge University Press.

Coaton, W.G.H. 1947. Biology of South African wood-eating termites. Journal of entomological Society of South Africa 9: 130-77.

Cooke, C.K. 1959. Rock art of Matabeleland, in R. Summers (ed.) Prehistoric rock-art of the Federation of Rhodesia and Nyasaland: 112-62. Salisbury: National Publications Trust.

Cooke, C.K. 1969. Rock art of Southern Africa. Cape Town: Books of Africa.

Crane, E. 1982. The archaeology of beekeeping. London: Duckworth.

Deregowski, J.B. 1995. Perception-DepictionPerception, and communication: a skeleton key to rock art and its significance. Rock-art Research 12: 3-22.

Dowson, T.A. 1988. Revelations of religious reality: the individual in San rock-art. World Archaeology 20: 116-28.

Frobenius, L. 1929. The mystery of South Africa's prehistoric art: newly discovered rock-drawings of divergent style-the problem of the age and affinities. The London Illustrated News: 333-5.

-1930. Prehistoric art in South Africa: “The King's monuments" - a unique series of rock-drawings recently discovered in Southern Rhodesia. The London Illustrated News: 338-41.

-1962 [1931]. Madsimu Dzangara. Graz: Akademische Druck.

Garlake, P.S. 1987. The painted caves. Harare: Modus Publications.

-1990 . Symbols of in the paintings of Zimbabwe. South African Archaeological Bulletin 45: 17-27.

-1995. The Hunter's vision: the prehistoric art of Zimbabwe. London: British Museum Press.

Goodall, E. 1959. The rock paintings of Mashonaland, in R. Summers (ed.) Prehistoric rock art of the Federation of Rhodesia and Nyasaland: 3-111. Salisbury: National Publications Trust.
Goodwin, A.J.H. 1946. Exhibition of prehistoric art in southern Africa. Cape Town: Jointly published by The South African Association of Arts \& The South African Archaeological Society.

GuY, R.D. 1972. The honey hunters of southern Africa. Bee World 53: 159-66.

HALL, R.N. 1912. The Bushmen, the first human occupiers of Rhodesia. Proceedings of the Rhodesian Scientific Association 11: 140-50.

Holm, E. 1957. Frobenius' cigars. South African Archaeological Bulletin 12: 68-9.

Howse, P.E. 1970. Termites: a study in social behaviour. London: Hutchinson University Library.

Huffman, T.N. 1983. The trance hypothesis and the rock art of Zimbabwe. The South African Archaeological Society Goodwin Series 4: 49-53.

Lee, D.N. \& H.C. Woodhouse. 1970. Art on the rocks of Southern Africa. Cape Town: Purnell.

LeWIs-Williams, J.D. 1981. Believing and seeing: symbolic meanings in southern San rock paintings. London: Academic Press.

Levin, H., M. Branch, S. Rappoport \& D. Mitchell. 1985. A field guide to the mushrooms of South Africa. Cape Town: Struik.

Marshall, J. \& C. Ritchie. 1984. Where are the Ju/wasi of Nyae Nyae? Cape Town: University of Cape Town Centre for African Studies Communications No. 9.

Mason, R.J. 1958. New prehistoric paintings in the Brandberg, South West Africa, and the Waterberg, Northern Transvaal. Lantern 7: 357-81.

Mguni, S. 2001. Research into the formlings in the rock art of Zimbabwe. Antiquity 75: 807-8.

-2002. Continuity and change in San belief and ritual: some aspects of the enigmatic formling' and tree motifs from Matopo Hills rock art, Zimbabwe. Unpublished MA Thesis. Johannesburg: University of the Witwatersrand.

-2004. Cultured representation: understanding 'formlings', an enigmatic motif in the rock-art of Zimbabwe. Journal of Social Archaeology 4: 181-99.

Nalepa, C.A. \& C. Bandi. 2000. Characterizing the ancestors: paedomorphosis and termite evolution, in T. Abe, D.E. Bignell \& M. Higashi (ed.) Termites: evolution, sociality, symbioses, ecology: 53-75. Dordrecht: Kluwer Academic.

Noirot, C.H. 1970. The nests of termites, in K. Krishna \& F.M. Weesner (ed.) Biology of termites (vol. 2): 73-125. New York: Academic.

Noirot, C. \& J.P.E.C. Darlington. 2000. Termite nests: architecture, regulation and defense, in T. Abe, D.E. Bignell \& M. Higashi (ed.) Termites: evolution, sociality, symbioses, ecology: 121-39. Dordrecht: Kluwer Academic. 


\section{'Formlings' in San rock paintings}

Nonaka, K. 1997. The role of edible insects in the dietary life of the 'IGui' and 'Gana' San in the central Kalahari Desert. (Journal title in Japanese) 3: 81-99.

Pager, H. 1971. Ndedema. Graz: Akademische Druck-und Verlagsanstalt.

-1973. Rock paintings in southern Africa showing bees and honey gathering. Bee World 54: 61-8.

-1976. Stone age myth and magic: as documented in the rock paintings of South Africa. Graz: Akademishce Druck-und Verlagsanstalt.

PARKIngton, J.E. 1989. Interpreting paintings without a commentary. Antiquity 63: 13-26.

PARRY, E. 2000. Legacy on the rocks: the prehistoric hunter-gatherers of the Matopo Hills, Zimbabwe. Oxford: Oxbow.

Patie, H.P. 1974. Bees or birds? Rhodesian Prehistory Society 6: 2-3.

Rudner, J. \& I. Rudner. 1970. The hunter and his art. Cape Town: Struik.

Smith, A.B. 1994. Metaphors of space: rock art and territoriality in southern Africa, in T.A. Dowson \& D. Lewis-Williams (ed.) Contested images: diversity in southern African rock-art research: 373-84.

Johannesburg: Witwatersrand University Press.
Turner, J.S. 2000. Architecture and morphogenesis in the mound of Macrotermes michaelensis (Sjöstedt) (Isoptera: Termitidae, Macrotermitinae) in northern Namibia. Cimbebasia 16: 143-75.

VAN Der Westhuizen, G.C.A. \& A. Eicker. 1994. Field guide: mushrooms of southern Africa. Cape Town: Struik.

Vinnicombe, P. 1976. People of the eland: rock paintings of the Drakensberg Bushmen as a reflection of their life and thought. Pietermaritzburg: University of Natal Press.

Uys, V. 2002. A guide to the termite genera of southern Africa. Pretoria: ARC-Plant protection Research Institute.

WaLKeR, N.J. 1996. The painted hills: rock art of the Matopos. Harare: Mambo Press.

Woodhouse, H.C. 1990. Bees and honey in the prehistoric rock art of southern Africa. The Digging Stick 6: 5-7. 